\title{
Strategies for the Chinese Translation of The Widow's Lament in Springtime in the Perspective of Comparative Poetics
}

\author{
Zhaohui Yan ${ }^{1}$ \\ ${ }^{1}$ Foreign Language Department, Zhengzhou University of Light Industry, China \\ Correspondence: Zhaohui Yan, Zhengzhou University of Light Industry, 5 Dongfeng Road, Jinshui District, \\ Zhengzhou 450002, China. Tel: 86-135-2651-9167. E-mail: robin76whitny78@126.com
}

This research is funded by Ministry of Education of the People's Republic of China (11YJA751011) and ZZULI educational reform project of 2012.

Received: February 1, 2013 Accepted: February 20, 2013 Online Published: April 26, 2013

doi:10.5539/ells.v3n2p9 URL: http://dx.doi.org/10.5539/ells.v3n2p9

\begin{abstract}
Since the beginning of "American new-style poetry campaign" in the $1910 \mathrm{~s}$, Chinese ancient poems have exerted influence on American poetry. As the outcome of Sino-Western poetics communication, The Widow's Lament in Springtime is a household poem. The poem has both Chinese and American poetic features. When translating this poem into Chinese, the translator should try his best to reproduce the Chinese and American characteristics. Negligence of either side will lead to the failure of the translation. It is in this sense that translation is a matter of poetics communication.
\end{abstract}

Keywords: comparative poetics, translating strategy, The Widow's Lament in Springtime

\section{Introduction}

As early as the "American new-style poetry campaign" in the $1910 \mathrm{~s}$, Chinese ancient poems began to exert influence on American poetry, and during the years of the 1950s and 1960s, the second high-tide period came into being. (Tan, 2008: 50) In the two periods, various ideological changes took place. In literary field, American modernistic poets were seeking "new values" to resist the old, out-dated poetics tradition. The influences on American new-style poetry campaign are very complicated. For American poetry of the early $20^{\text {th }}$ century, English poetics tradition is the heritage that should be got rid of. Chinese poems, together with French poems, exerted major influences on "American new-style poetry campaign". (Zhao, 2003: 136)

The "Dissemination of Oriental Learning to the West" in the field of poetry resulted in the communications between Sino-western poetics. With Ezra Pound as the representative, many poets took an active part in translating and imitating Chinese poems and many of the mimical works became classical poems. Of the successful mimical poems, The Widow's Lament in Springtime is a good example:

The Widow's Lament in Springtime

Sorrow is my own yard

where the new grass

flames as it has flamed

often before but not

with the cold fire

that closes round me this year.

Thirtyfive years,

I lived with my husband.

The plumtree is white today

with masses of flowers.

Masses of flowers

load the cherry branches

and color some bushes 
yellow and some red

but the grief in my heart

is stronger than they

for though they were my joy

formerly, today I notice them

and turned away forgetting.

Today my son told me

that in the meadows,

at the edge of heavy woods

in the distance, he saw

trees of white flowers.

I feel that I would like

to go there

and fall into those flowers

and sink into the marsh near them.

(Liu, 2003: 467-468)

As the outcome of Sino-Western poetics communication, The Widow's Lament in Springtime is a household poem. Whether in terms of the theme or the artistic realm, the poem is different from traditional western poems. The Widow's Lament in Springtime is much more like Chinese ancient "feminine querimony poetry", displaying endless oriental poetic beauty. In the following parts, the author will take the poem for example to explore the issue of Sino-western poetics communication of the early $20^{\text {th }}$ century.

\section{Dissemination of Oriental Learning to the West in American New-Style Poetry Campaign}

In the late $19^{\text {th }}$ century and the early $20^{\text {th }}$ century, traditional poets of the elegant school were in the dominant position. (Zhao, 1985: 206) They spared no efforts to imitate English poems and until the beginning of the new-style poetry campaign they were not independent from English poetics tradition, in a position of subordination. Modernistic poets were antipathetic to this phenomenon.

American new-style poetry campaign was a conscientious one, which aimed to make American poems Americanized. Therefore, the task of this campaign is not only to get rid of the pressure of orthodox English literature but also to loosen the restriction of orthodox European culture. (Zhong, 2003: 236) The influence of French symbolism on American poetry was two-sided. On the one hand, due to the influence of symbolism, some poets of new-style poetry campaign broke away from Victorian tradition and became modernistic poets. On the other hand, symbolism could merge with English poetics tradition to form European orthodoxy, weakening the features of Americanization of American poems. (Zhang, 2001: 93) As a result, American poets turned to the other side of the Pacific ocean to seek resistant force. Although, in the beginning of the campaign Chinese poetry exerted no direct influence on American poetry, American poets were sure to turn to China after they had contacted with Japanese, because as far as the new-style poetry campaign was concerned, the part played by Japanese poetry was to introduce Chinese poetry into America. (Zhao, 2003: 285)

Today's readers have little interest in the active poets of the new-style poetry campaign, but their classical poems are mostly "Chinese poems". (Hu, 2011: 33) At that time, quite a few poets won great reputation by imitating Chinese poems, or writing poems of Chinese subject matter. That was the tide of the era, not one or two people's fever. In June 1915, Pound pointed out that reading Chinese poems could help people get the idea of imagism. In September 1915, Monroe defined imagism as the pursuit of Chinese magic. And in 1916, Aiken commented the sensation caused by Waley's translation of Chinese poem by referring to it as "oriental spiritual intrusion". (Zhao, 2003: 188)

\section{Williams: A Poet Actively Deriving Alimentation from Chinese Poetics}

When it comes to the relationship between American modern poems and Chinese poetry, Ezra pound is the first to come into people's mind. In the early period of the American new-style poetry campaign, Pound took the lead in creating new style of poems, becoming the leader of the campaign. Due to the clear images, novel forms and fresh details, the poems of imagism attracted a great number of American poets at that time. (Geng, 2002: 68)

Because of close association with Pound, Williams not only realized the tremendous significance of Pound's work, but also tried to understand and draw lessons from Chinese poems. (Williams, 1967: 98) He once said in his letter to Pound, "it seems that ancient Chinese poets knew life better than us. "From this comment, it can be inferred that Williams had had a deep understanding of Chinese traditional poetry. Williams also translated 
thirty-seven Chinese poems in collaboration with David Wang. He ever wrote two poems respectively entitled To the Spirit of Bai Juyi (1920) and The Portrait of the Author (1921), in which Williams borrowed the images of singing girl and "Yang Kue Fei" (concubine of Minghuang Emperor of the Tang Dynasty), who appeared in Bai Juyi's poems before. In addition, the frequently used images of the moon, the willow trees and raindrops mostly have certain relations with ancient Chinese poems. (Geng, 2002: 67-68)

Compared with Pound, Williams directly borrowrd less from Chinese poems. This suggests that Pound was very prudent in accepting and borrowing Chinese ancient poems, which was unlike the indiscriminate borrowing and employment of Pound. But whether in terms of borrowing the expressive forms of Chinese characters and poetry or in terms of the understanding of Chinese poetry's inherent spirit, Williams was not in shade at all.

\section{The Widow's Lament in Springtime: A Classic as the Outcome of Sino-Western Poetic Communication}

As Ezra Pound's close friend, Williams not only showed great interest in Chinese poems but also actively tried the new techniques he discovered in Chinese poems. This made many of his poems display Chinese poetic features. As the outcome of the Sino-Western poetics communication, The Widow's Lament in Springtime is a very famous love poem with Chinese poetic characteristics.

\subsection{Learning the Technique of Plain Diction from Bai Juyi}

Bai Juyi is a famous poet of the Tang Dynasty, and Williams likes Bai Juyi's poems, regarding him as his spiritual friend without any actual contacts. It is recorded that Bai Juyi liked to use plain words in his poems. Whenever he wrote a poem, he would read it to illiterate old ladies. If they could not understand the poem, he would revise it until they could understand. (Xin, 957: 482) Therefore, Bai Juyi's poems are easy to understand and very popular among common people. He left many household classic poems. Williams has great interest in Bai Juyi's poems and liked to borrowed ideas and images from Bai Juyi into his own poems. Above mentioned To the Spirit of Bai Juyi and The Portrait of the Author can be good examples. Therefore, it is easy to infer that Bai Juyi's linguistic feature has great influence on Williams. In the whole poem of The Widow's Lament in Springtime, all words are colloquial, simple and plain, which makes the poem read natural and friendly. The endless sorrow is expressed by the means of plain words and the poem is suitable for the elegant people and the common ones. What deserves our special attention is the use of the words of "cold"and "white". The two common words appear in the poem many times, and help a great deal in highlighting the theme.

\subsection{Borrowing the Technique of Implicit Expression}

Implicit expression refers to the technique of expressing meanings in an indirect way, not in a clear way. The meaning intended is expressed through the image in the poems. Implicit expression leaves room for readers to think and to seek, and the connotation of the poem will become richer and richer because of the readers' association and imagination. The wonderful artistic realm is created through the creative appreciation of the readers. (Hu, 2011: 34) Just as Su Shi said, "The most powerful expression is to convey endless meaning with limited words." (Zhou, 1997: 248)

At first sight, The Widow's Lament in Springtime is easy to understand because the words used in it are plain. But after consideration, the authors leave us many questions for us to think over. Does the phrase "my own yard"refer to the observable yard? As we all know, the phrase "one's own" means that something is possessed by the owner himself and can not be shared by anyone else. But from the poem, we know the widow has a son, and so the yard is not owned by her alone. We can infer that the phrase "my own yard" refers to the widow's inward world. Then, we can infer the "new grass" is symbolic of the love arising in his heart. Even, the beautiful landscape in the poem is completely an imagined picture. Knowing this, we will easy grasp the poem's idea. The author expressed endless meanings by using limited plain words. In addition to symbolism, the poet also uses spelling skills to convey special meanings. The author deliberately misspelled "thirty-five" into "thirtyfive". Omission of the hyphen makes the word closely combined. The implicit meaning is that "in the thirty-five years, we are not separated, just like the word." All the effects are achieved by the means of implicit expression.

\subsection{Borrowing the Technique of Expressing Feelings by Depicting Landscape}

English nature poems bear some similarity to Chinese landscape poems, but they are greatly different in the form of expression. Traditional English nature poems have clear demarcation between subjects and objects, and the former is superior to the latter. On the contrary, in Chinese ancient landscape poems, there is no clear separation between subjects and objects. Subjects and objects can be blended, or subjects are moved by the images of the subjects.

In feminine querimony poems, it is common for poets to construct artistic realm with natural objects like flowers, grass and trees for the purpose of reflecting the plaintive emotion of the females. In The Widow's Lament in 
Springtime, the poet paints a landscape of the spring courtyard: "the new grass flames as it has flamed often before...The plumtree is white today /with masses of flowers./Masses of flowers /load the cherry branches /and color some bushes /yellow and some red".

The yard, the new grass, the plumtree, the flowers are all common objects, but they incurred the endless changes and associations of the widow. The widow remembered the happy days spent together with her husband. In the past thirty-five years, they lived together, and the flowers witnessed their happiness. But here and now, flowers are contending in beauty, the land is displaying vitality, and the new grass which is symbolic of the budding of love is flaming, but the widow is alone, helpless and lonely. The poet doesn't express the deep sorrow directly, but the sorrowful feelings is written into the lines, "I feel that I would like /to go there /and fall into those flowers /and sink into the marsh near them." This way of expressing feelings is very familiar to Chinese readers, and so Williams realizes the combination of the ways of expressing emotions of western and oriental poems.

\subsection{Choosing the Subject Matter of Feminine Querimony Poetry}

Feminine querimony poetry is a common subject matter in Chinese poetry. In ancient China, husbands had the freedom of traveling around and the right of having many wives. Women were strictly restricted by feudal moral and institutional systems, and so they were in a disadvantaged position. Their living space was confined to their family, and they were often given the cold shoulder, and were even abandoned. Once abandoned, they had no other choice but to live alone for the rest of their lives.

Therefore, in ancient poetry field, the feminine querimony poetry came into existence. It is a special kind of poems designed for women to expressing their missing, loneliness, and complaints. Together with frontier fortress poetry, pastoral poetry and landscape poetry, feminine querimony poetry became an indispensable part of Chinese ancient poetry. Feminine querimony poetry is suitable for expressing moving affections, displaying sorrowful and sentimental beauty. The words used in feminine querimony poetry are always plain but rich in meaning.

There is a unique phenomenon in feminine querimony poetry, namely, many feminine querimony poems were written by male literati. They wrote the poem in the tone of women by imagining themselves in the women's position. In American society, women had comparatively high social status with Chinese women and they were less restricted than Chinese women. Compared with Chinese women, American women had more favorable social position as far as love and marriage is concerned. Therefore, America has no necessary prerequisites for the appearance of feminine querimony poems. Since new-style poetry campaign, modernistic poets have absorbed this subject matter, and a few feminine querimony poems appeared. (Cai, 2006: 71) The Widow's Lament in Springtime is the representative. The author wrote the poem in the first person and expressed the widow's plaintive feelings. The poem is much the same as traditional Chinese feminine quarryman poems.

\section{Strategies for Translating The Widow's Lament in Springtime}

The Widow's Lament in Springtime is the outcome of Sino-Us poetics communication. On the one hand, it has the features of American poems; on the other hand, the poem has the features of Chinese poems. The plain diction, the deliberate syntactic structure, the Phonological characteristics are the main traits for the translators to reproduce.

\subsection{Reproducing the Original Syntactical Structure to Convey the Sorrow}

The first six lines of the original constitute a long composite sentence, which conveys the confused feelings of the author through the complicated structure. The long sentence is an inverted one. Here are two Chinese versions of this stanza:

$\begin{array}{ll}\text { Version I } & \text { Version II } \\ \text { 我的庭院满目悲凉 } & \text { 我的庭院是哀愁 } \\ \text { 遍地新草 } & \text { 那儿初生的嫩草 } \\ \text { 火光般闪耀 } & \text { 依旧灼灼欲燃 } \\ \text { 年年相似 } & \text { 像往常一般 } \\ \text { 但今年的火光格外清冷 } & \text { 可是今年却以 } \\ \text { 紧紧包围我。 } & \text { 冷冷的火焰包围我。 } \\ \text { (Liu, 2003: 471) } & \text { (Zhong, 2001: 153) }\end{array}$

In poems, if a sentence is inverted, the reason may be one of the following three: for the sake of rhyming, for the 
sake of syntactic correction, or for the sake of emphasis. Here, there is no need to invert the sentence for the sake of rhyming because the poem is unrhymed. The reason why the sentence is inverted is, on the one hand, to make the sentence grammatically correct and, on the other hand, to emphasize the word "sorrow", and the latter is more important. The above two versions are both in natural order, which is not in consistence with the original in form and also violates the original in meaning. In addition, the above two versions are both made up of comparatively isolated phrases, which helps achieve the effect of smoothness but the leaden heart and sadness is lost. Look at the following version on my own:

$$
\begin{aligned}
& \text { 哀愁充斥我的庭院 } \\
& \text { 庭院里的新草 } \\
& \text { 依旧火焰般闪耀 } \\
& \text { 一如往常, 可 } \\
& \text { 今年围绕着我的却是 } \\
& \text { 清冷的火焰。 }
\end{aligned}
$$

In this version, the reverted order of the original is retained, and so the emphasis of the word "sorrow" is kept. Meanwhile, each line is not isolated but linked together by the repetition of “庭院”, adversative conjunctions of “可” and “却是”. Therefore, the original meaning has been in large degree conveyed.

\title{
5.2 Choosing Plain Words to Retain the Original Linguistic Feature
}

The use of plain words is a very distinct feature of The Widow's Lament in Springtime, which makes the poem very striking and intimate. On the one hand, the simplicity of diction embodies the poet's consistent writing style; on the other hand, the use of simple words is the necessity of expressing sorrow emotions, for it is impossible for a sad person to use fine words. The following is a translation of the $9^{\text {th }}$ to $14^{\text {th }}$ lines:

$$
\begin{aligned}
& \text { 今天的梨树一片洁白 } \\
& \text { 满树银花 } \\
& \text { 压着樱桃树枝 } \\
& \text { 把灌木丛染得 } \\
& \text { 一片翠绿, 一片嫩黄 }
\end{aligned}
$$

(Liu, 2003: 471)

Compared with the original, the diction of the translation is more flowery. The translator renders "white" into “洁白(snow white)”, “white flower” into “银花(silvery flower)”, “green ” into “翠绿(emerald)”, “yellow” into “嫩黄(tender yellow)". These words are not simple colloquial words, because they are all too elegant and flowery, which undermines the original linguistic feature and distorts the emotion of the author. The following is another version:

$$
\begin{aligned}
& \text { 今天李树一片白 } \\
& \text { 满树累累的花朵。 } \\
& \text { 累累的花朵 } \\
& \text { 曾压低樱桃树枝 } \\
& \text { 而今替不少灌木丛着色 } \\
& \text { 一些染红, 一些染黄 }
\end{aligned}
$$

(Zhong, 2001: 153)

\subsection{Employing End Rhymes to Compensate for the Phonological Loss}

Liu Shoulan translated the last four lines into:

\author{
我觉得我真想 \\ 到那里去 \\ 落入洁白的花从 \\ 沉入近旁的沼泽。
}

(Liu, 2003: 471) 
The original is not rhymed, but should the translator use end rhyme? Phonological systems of Chinese and English are quite different, and so it is impossible to reproduce the tunable and cadential feature of the original in the Chinese translation. But if a good poem is deprived of cadence and tune, is it still a good poem? Especially, Chinese poets place great emphasis on rhyming, creative reproduction of the poem's phonological beauty by employing some supplementary techniques is very necessary.

Zhang Chuanbiao's rhymed version is: “怦然心动, /何不融入花丛? 对, 我要前去, /沉入花旁泥中! ” (Zhang, 2005, p. 59) Here, the translator uses “动(dong)" at the end of the first line, “从(cong)"at the end of the second line, and "中(zhong)" at the end of the forth line. The translated stanza is rhymed. Although the original phonological beauty is not fully displayed, the similar phonological beauty is creatively reproduced by the means of end rhyme.

\subsection{Highlighting Some Factors to Compensate for the Lost Meaning Implicated by Special Techniques}

There is a very unique phenomenon in The Widow's Lament in Springtime, namely deliberate misspelling. In the lines "Thirtyfive years/ I live with my husband", the word "thirtyfive" is the wrong spelling for "thirty-five". Just because of the omission of the hyphen, the two elements of the composite word "thirty" and "five" are closely combined together. By dong so deliberately, the author implicates that she and her husband in the thirty-five years lived happily together without any estrangement. The following are three versions:

$\begin{array}{ll}\text { Version } 1 & \text { Version } 2 \\ \text { 三十五载, } & \text { 我跟丈夫共度了 } \\ \text { 我和丈夫朝夕相处。 } & \text { 三十五年。 }\end{array}$

(Liu, 2003: 471)

(Zhong, 2001: 153)
Version 3

三十五个寒暑,

夫妻偕度时光。

(Zhang, 2005: 59)

In the above three versions, the translators all neglect the implicated meaning, which results in the loss of the deeper connotation than that directly expressed by the linguistic signs. If some words are added to the translation to highlight the closeness of the couple's intimate relationship, the loss will be compensated for. Look at the following version on my own:

三十五载,

我和丈夫相濡以沫。

“相濡以沫” is an idiom, which originated from a Chinese fable story. Two fish lived in a puddle. When the water in the puddle diminished and diminished, the two fish were exposed to the air, and their lives were endangered. They helped each other by making the other moist with its saliva. The symbolic meaning of this idiom is that people go through hardships hand in hand. By using this word, the matchlessly intimate relationship is displayed although the unique spelling technique can not be duplicated.

\section{Conclusion}

During the "American new-style poetry campaign", some Chinese poems were absorbed by American modernistic poets, but the poems were to some degree misunderstood, although the misunderstanding didn't change the inherent nature of Chinese poems. The poets highlighted some factors of the poems so that they could be suitable for the need of the campaign. As far as some concrete factors were concerned, Chinese poems could be misunderstood, but in general Chinese poetry did not exert influence on American poetry through misunderstanding. (Zhang, 2001: 79) According to their understanding, modernistic poets wrote some poems by imitating Chinese poems, and they made great achievements. But whether in form or in technique, the imitative poems they composed are not idiomatic Chinese poems, but the outcome of Sine-Western poetics communication.

Therefore, when translating this kind of poems, we should study the original carefully. After knowing what factors are Chinese, and what factors are foreign, the translator should try his best to reproduce all kinds of features of the original in his translation. It is a great challenge for poetry translators. In many cases, the translator is misled by his pre-understanding. In translation, he emphasizes one feature, neglecting the other. The reason is the lack of poetics knowledge of the target language and the source language. Therefore, translation is not only a matter of transformation of linguistic signs but also a matter of poetics communications. (Yue, 2004: 338) 


\section{References}

Cai, M. (2006). A Preliminary Study of the Relationship between William Carlos Williams' Imagism Poems and Chinese Cultural Tradition. Journal of Xi'an Aerotechnical College, 26(3), 68-72.

Geng, Y. (2002). William Carlos Williams and Chinese poems. Chinese Book Review Monthly, 7(9), 66-70.

Halter, P. (1994). The Revolution in the Visual Arts and the Poetry of William Carlos Williams (p. 216). London: Cambridge University Press.

Hu, L. (2011). Faint American Poetry, Deep Love of China-Appreciation on The Widow's Lament in Springtime by William Carlos Williams. Journal of Xichang College (Social Science Edition), 23(1), 33-35.

Liu, S. (2003). Analysis and Appreciation of English and American Poems (pp. 467-471). Shanghai: Shanghai Foreign Language Education Press.

Tan, D. (2008). The Translation and Acceptance of Chinese Ancient Poems of American Modernistic Poets. Journal of Chongqing Normal University Edition of Social Sciences, 28(2), 48-53.

Williams, W. C. (1967). The Autobiography of William Carlos Williams (pp. 200-203). New York: New Directions Publishing Corporation.

Xin, W. (1957). Biographies of the Gifted Scholars of the Tang Dynasties (p. 204). Shanghai: Ancient Classics Publishing House.

Yue, D. (2004). The Ten Lectures on Comparative Literature and Comparative Culture (p. 338). Shanghai: Fudan University Press.

Zhang, C. (2005). The Poetic Pen - The Translation Pen - The Blunt Pen: English-Chinese Translation and Comparison (p. 59). Beijing: Defense Industry Publishing Company.

Zhang, Q. (2001). Imagism, Pound, and the Origin of American Modernistic poems. Foreign Literature Studies, 23(1), 88-95.

Zhang, Y. (2001). Exotic Atmosphere and Indigenous Ideologies - the Dialog between William Carlos Williams and China. Foreign Literature Review, 14(4), 77-84.

Zhao, Y. (1985). Muse Traveling Faraway: The Influence of Chinese Ancient Poems on American New-Style Poetry Campaign (p. 206). Chengdu: Sichuan People's Publishing House.

Zhao, Y. (2003). Muse Travels Faraway: How China Changed American Modernistic Poems (p. 136). Shanghai: Shanghai Translation Publishing House.

Zhong, L. (2003). American Poems and Chinese Dreams (p. 153). Guilin: Guangxi Normal University Press.

Zhou, Y. (1997). The General Theory of the Poetics of the Song Dynasties (p. 248). Chengdu: Bashu Publishing House.

\section{Author}

Zhaohui Yan was born in Henan, China in 1976. He received his M.A. in English language and literature from Shanghai Institute of Foreign Trade, China in 2005. He is currently a lecturer in Foreign Languages Department, Zhengzhou University of Light Industry, Henan, China. His research interests include bilingual translation between English and Chinese, cross-cultural communication. 